\title{
Perceptions, attitudes and preferences in agroforestry among rural societies of Kashmir, India
}

\author{
M. A. Islam", T. H. Masoodi, S. A. Gangoo, P. A. Sofi, G. M. Bhat, A. A. Wani, A. A. Gatoo, \\ Amerjeet Singh and A. R. Malik
}

Faculty of Forestry, Sher-e-Kashmir University of Agricultural Sciences \& Technology of Kashmir, Wadura, Sopore-193201 (J\&K), INDIA

"Corresponding author. E-mail: ajaztata@gmail.com

Received: May 22, 2015; Revised received: October 11 2015; Accepted: November 27, 2015

\begin{abstract}
People's perceptions, attitudes and preferences in agroforestry have become fundamental elements of sustainable agroforestry management. The study examined the multiplicities and dimensions of people's perceptions about agroforestry values, attitudes towards agroforestry benefits and resources preferences in agroforestry and their socioeconomic determinants in rural societies of Kashmir. The data were collected from 142 households of 5 villages selected employing multi-stage random sampling. Descriptive and analytical statistics were used for the data analysis. Results indicated that the material values (rank $1^{\text {st }}$ to $3^{\text {rd }}$ ) of agroforestry were perceived as the most important while the perception of the non-material values (rank $4^{\text {th }}$ to $10^{\text {th }}$ ) were adjudged moderately important. People's attitudes towards the tangible benefits (rank $1^{\text {st }}$ to $3^{\text {rd }}$ ) of agroforestry were highly favourable whereas attitudes towards intangible benefits (rank $4^{\text {th }}$ to $10^{\text {th }}$ ) were indifferent. The rural people expressed higher preferences for fuel wood, fodder, vegetable, fruit, and timber (rank $1^{\text {st }}$ to $5^{\text {th }}$ ) while moderate or low preferences for medicine, cottage industry/ handicrafts, fiber/ floss, oilseeds and animals/ birds/ insects etc. (rank $6^{\text {th }}$ to $10^{\text {th }}$ ). F statistics $(p<$ 0.05 ) showed significant differences between the material and non-material values, tangible and non-tangible benefits and resources groups. Correlation co-efficients ( $r$ ) confirmed the importance of socioeconomic attributes in influencing people's perceptions, attitudes and preferences in agroforestry. The findings will help to refine and enrich the knowledge-base to provide an effective framework for decisions and policy making to sustain and maintain agroforestry health and services. The integration of people's socio-psychological conditions in sustainable agroforestry management will be effective strategy commensurating the current development and future challenges.
\end{abstract}

Keywords: Agroforestry, Attitudes, Perceptions, Preferences, Socioeconomic attributes

\section{INTRODUCTION}

The sustainable agroforestry management paradigm aims to balance the social, economic, ecological, and cultural needs of present and future generations and to maintain and conserve forest resources besides offering the multiple uses (Nagesha and Gangadharappa, 2006; Roy and Tiwari, 2012). Direct integration of people's perceptions, attitudes and preferences in the decision making process is an important aspect of sustainable agroforestry management, because it can increase the social acceptance of the decisions and reduce differences among stakeholders (Islam et al., 2005; Dagar, 2012). Perceptions of agroforesty values build up enduring concepts of what is good and desirable, or conversely, bad and undesirable, about agroforestry (Banyal et al., 2011; Khandagale et al., 2012; Palett et al., 2013). Agroforestry values can be divided into two categories: material (economic and life supporting) and non-material (socio-cultural, ethical, spiritual, and aesthetic). They can also be classified as either intrinsic or instrumental. Intrinsic values relate to the contribution of action to maintain the health and ISSN : 0974-9411 (Print), 2231-5209 (Online) All Rights Reserved ( $)$ Applied integrity of an agroforestry ecosystem or the conservation of species, while instrumental values involve satisfying human needs or wants such as aesthetic, cultural, spiritual values etc. These values vary from culture to culture, region to region and societies to societies and over time, whose importance has grown in recent decades (Bijalwan et al., 2011; Ratsimbazafy et al., 2012). The success of long-term sustainable management of forest resources through agroforestry depends on local people's support (Islam et al., 2006). Assessing local people's attitudes, taking into account their needs, aspirations and respecting their opinions should become an adoption and management priority (Kareemulla et al., 2009; Macura et al., 2011). The favourable attitudes of people assure agroforestry promotion and development while unfavourable attitudes create agroforestry non-adoption and failure (Khandagale et al., 2012; Ratsimbazafy et al., 2012). The attitudes influence human behaviors towards agroforestry acceptance and encouragement (Pant, 2011). The forest resources preferences in agroforestry contribute much to understanding of agroforestry planning, implementation and management (Quli and Singh, 2010; Ratsimbazafy et 
al., 2012). Resources preferences in agroforestry are likely to be influenced by many factors, both on-site, such as household needs, local usage perspectives, livelihood dependency etc., and off-site, such as proximity to marketing infrastructures, cottage industries, centers of population, availability of alternative substitutes etc. (Mushtaq et al., 2012; Edwards et al., 2012). To appropriate the forest resources preferences in agroforestry among rural people, focus on structure and function of agroforestry plantations is imperative which is achieved by standardizing the agroforestry management regimes (Rawat and Vishvakarma, 2011). An analysis of people's perceptions, attitudes and preferences in agroforestry is fundamental to agroforestry planning and management, because people's knowledge has the potential to effectively support decisionmakers in the management and preservation of forest resources (Reddy, 2011). The agroforestry management initiatives worldwide have embraced ecological management integrated with socio-economic and psychological decisions because the targets of ecosystem services cannot be achieved through environmental understanding alone (Mukherjee, 2013). Moreover, being aware of people's perceptions, attitudes and preferences in agroforestry is important for designing and implementing management policies (Sood et al., 2008). This aspect is particularly significant in valleys in general and the Kashmir valley in particular. The Kashmir valley is characterized by a strong link be- tween local communities and agroforestry and by particular attention to agroforestry multi-functionality (Banyal et al., 2011). Agroforestry plantations have become a rural way of life in Kashmir valley since time immemorial (Islam et al., 2012). The common agroforestry systems being practiced traditionally in Kashmir valley are agri-silvi-horticulture and homestead forestry. The woody and fruit tree species most commonly adopted for agroforestry plantations are Salix alba, Populus deltoides, Robinia pseudoacacia, P. nigra, Morus alba, Juglans regia, Ulmus wallichiana, Ailanthus excelsa, Malus domestica, Pyrus communis, Prunus persica, P. armeniaca etc. A deeper understanding of people's perceptions, attitudes, and preferences in agroforestry is imperative for framing an appropriate policies and management plans to sustain and maintain agroforestry structure and functions in Kashmir. The present study is an attempt to investigate the multiplicities and dimensions of people's perceptions about agroforestry values, attitudes towards agroforestry benefits and resources preferences in agroforestry and their relationship with socioeconomic factors, as a basis for suggestions of strategies for sustainable management of the agroforestry resources and improvement of the livelihoods of rural societies.

\section{MATERIALS AND METHODS}

Study site: The study was carried out in Baramulla and Kupwara districts in north-western region of Kash-

Table 1. Descriptive statistics for socioeconomic characteristics of rural people in Kashmir (N=142).

\begin{tabular}{|c|c|c|c|c|c|c|}
\hline \multirow[t]{2}{*}{ Characteristic } & \multirow[t]{2}{*}{ Mean } & \multirow[t]{2}{*}{ Std. Dev. } & \multicolumn{2}{|c|}{ 95\% Confidence Interval for Mean } & \multirow[t]{2}{*}{ Minimum } & \multirow[t]{2}{*}{ Maximum } \\
\hline & & & Lower Bound & Upper Bound & & \\
\hline Age & 41.75 & 9.53 & 40.17 & 43.33 & 25 & 56 \\
\hline Education & 2.89 & 0.93 & 2.73 & 3.04 & 2 & 6 \\
\hline Social participation & 1.14 & 1.20 & 0.94 & 1.34 & 0 & 4 \\
\hline Family composition & 2.90 & 0.88 & 2.76 & 3.05 & 2 & 4 \\
\hline Size of land holding & 1.15 & 0.53 & 1.06 & 1.24 & 1 & 4 \\
\hline Main occupation & 2.80 & 1.20 & 2.61 & 3.00 & 1 & 6 \\
\hline Housing status & 3.57 & 1.01 & 3.40 & 3.74 & 2 & 6 \\
\hline Farm power & 1.04 & 0.64 & 0.94 & 1.15 & 0 & 3 \\
\hline Farm implements & 9.64 & 3.78 & 9.01 & 10.27 & 4 & 17 \\
\hline Livestock possession & 1.91 & 0.56 & 1.82 & 2.00 & 0 & 3 \\
\hline Wealth status & 8.09 & 3.36 & 7.53 & 8.65 & 2 & 15 \\
\hline Gross annual income & 50887.32 & 21134.19 & 47381.15 & 54393.49 & 18000 & 95000 \\
\hline
\end{tabular}

Table 2. Perceptions about agroforestry values in the rural societies of Kashmir (N=142).

\begin{tabular}{lccccc}
\hline Agroforestry values & Highly important & $\begin{array}{c}\text { Perception } \\
\text { Moderately important }\end{array}$ & $\begin{array}{c}\text { WMS } \\
\text { Least important }\end{array}$ & $\begin{array}{c}\text { Mean } \\
\text { rank }\end{array}$ \\
\hline Productive & $120(84.51)$ & $22(15.49)$ & $00(0.00)$ & $2.85^{\mathrm{a}}$ & 1 \\
Protective & $75(52.82)$ & $52(36.62)$ & $15(10.56)$ & $2.42^{\mathrm{b}}$ & 5 \\
Social & $76(53.52)$ & $53(37.32)$ & $13(9.16)$ & $2.44^{\mathrm{b}}$ & 4 \\
Economic & $118(83.10)$ & $24(16.90)$ & $00(0.00)$ & $2.83^{\mathrm{a}}$ & 2 \\
Human & $107(75.35)$ & $33(23.24)$ & $02(1.41)$ & $2.74^{\mathrm{a}}$ & 3 \\
Ecological & $63(44.37)$ & $55(38.73)$ & $24(16.90)$ & $2.27^{\mathrm{b}}$ & 6 \\
Cultural & $49(34.51)$ & $45(31.69)$ & $48(33.80)$ & $2.00^{\mathrm{b}}$ & 8 \\
Recreational & $34(23.94)$ & $77(53.23)$ & $31(22.83)$ & $2.02^{\mathrm{b}}$ & 7 \\
Spiritual & $45(31.69)$ & $48(33.80)$ & $49(34.51)$ & $1.97^{\mathrm{b}}$ & 10 \\
Organizational & $45(31.69)$ & $50(35.21)$ & $47(33.10)$ & $1.99^{\mathrm{b}}$ & 9 \\
\hline
\end{tabular}

WMS $=$ Weighted mean score, Figures in the parentheses indicate percentages; Means followed by different superscript letters within the column are significantly different $(\mathrm{p}<0.05)$ 
Table 3. Attitude towards agroforestry in the rural societies of Kashmir $(\mathrm{N}=142)$.

\begin{tabular}{|c|c|c|c|c|c|c|c|}
\hline \multirow[t]{2}{*}{ Statement } & \multicolumn{5}{|c|}{ Response category } & \multirow[t]{2}{*}{ WMS } & \multirow{2}{*}{$\begin{array}{c}\text { Mean } \\
\text { rank }\end{array}$} \\
\hline & SA & A & $\mathbf{U}$ & D & SDA & & \\
\hline $\begin{array}{l}\text { Agroforestry helps people to become self-reliant in } \\
\text { terms of fuel wood, fodder, timber and other non- } \\
\text { timber forest produces (NTFPs) }\end{array}$ & $\begin{array}{c}40 \\
(28.17)\end{array}$ & $\begin{array}{c}102 \\
(71.83)\end{array}$ & $\begin{array}{c}00 \\
(0.00)\end{array}$ & $\begin{array}{c}00 \\
(0.00)\end{array}$ & $\begin{array}{c}00 \\
(0.00)\end{array}$ & $4.28^{\mathrm{a}}$ & 1 \\
\hline $\begin{array}{l}\text { Agroforestry provides employment and income } \\
\text { opportunities to the people at their door steps }\end{array}$ & $\begin{array}{c}33 \\
(23.24)\end{array}$ & $\begin{array}{c}109 \\
(76.76)\end{array}$ & $\begin{array}{c}00 \\
(0.00)\end{array}$ & $\begin{array}{c}00 \\
(0.00)\end{array}$ & $\begin{array}{c}00 \\
(0.00)\end{array}$ & $4.23^{\mathrm{a}}$ & 2 \\
\hline $\begin{array}{l}\text { Agroforestry reduces exodus of rural people to ur- } \\
\text { ban areas for their livelihood }\end{array}$ & $\begin{array}{c}10 \\
(7.04)\end{array}$ & $\begin{array}{c}45 \\
(31.69)\end{array}$ & $\begin{array}{c}38 \\
(26.76)\end{array}$ & $\begin{array}{c}31 \\
(21.83)\end{array}$ & $\begin{array}{c}18 \\
(12.68)\end{array}$ & $2.98^{\mathrm{b}}$ & 6 \\
\hline $\begin{array}{l}\text { People can improve their socio-economic condi- } \\
\text { tions by adopting the agroforestry based enterprises }\end{array}$ & $\begin{array}{c}19 \\
(13.38)\end{array}$ & $\begin{array}{c}61 \\
(42.96)\end{array}$ & $\begin{array}{c}34 \\
(23.94)\end{array}$ & $\begin{array}{c}25 \\
(17.61)\end{array}$ & $\begin{array}{c}03 \\
(2.11)\end{array}$ & $3.47^{\mathrm{b}}$ & 4 \\
\hline $\begin{array}{l}\text { Agroforestry supplies sufficient raw materials for } \\
\text { forest resources based cottage industries and handi- } \\
\text { crafts }\end{array}$ & $\begin{array}{c}27 \\
(19.01)\end{array}$ & $\begin{array}{c}112 \\
(78.87)\end{array}$ & $\begin{array}{c}03 \\
(2.12)\end{array}$ & $\begin{array}{c}00 \\
(0.00)\end{array}$ & $\begin{array}{c}00 \\
(0.00)\end{array}$ & $4.17^{\mathrm{a}}$ & 3 \\
\hline $\begin{array}{l}\text { Practice of agroforestry has helped in amelioration } \\
\text { of the microclimate of the area }\end{array}$ & $\begin{array}{c}00 \\
(0.00)\end{array}$ & $\begin{array}{c}26 \\
(18.31)\end{array}$ & $\begin{array}{c}41 \\
(28.87)\end{array}$ & $\begin{array}{c}51 \\
(35.92)\end{array}$ & $\begin{array}{c}24 \\
(16.90)\end{array}$ & $2.48^{\mathrm{c}}$ & 10 \\
\hline $\begin{array}{l}\text { Agroforestry practices assures maintenance of eco- } \\
\text { logical balance }\end{array}$ & $\begin{array}{c}00 \\
(0.00)\end{array}$ & $\begin{array}{c}32 \\
(22.53)\end{array}$ & $\begin{array}{c}44 \\
(30.99)\end{array}$ & $\begin{array}{c}42 \\
(29.58)\end{array}$ & $\begin{array}{c}24 \\
(16.90)\end{array}$ & $2.59^{\mathrm{b}}$ & 8 \\
\hline $\begin{array}{l}\text { The agroforestry is successful in meeting social, } \\
\text { cultural, religious and recreational needs of the } \\
\text { people }\end{array}$ & $\begin{array}{c}16 \\
(11.27)\end{array}$ & $\begin{array}{c}53 \\
(37.32)\end{array}$ & $\begin{array}{c}41 \\
(28.87)\end{array}$ & $\begin{array}{c}25 \\
(17.61)\end{array}$ & $\begin{array}{c}07 \\
(4.93)\end{array}$ & $3.32^{\mathrm{b}}$ & 5 \\
\hline $\begin{array}{l}\text { Adoption of agroforestry helps in soil and water } \\
\text { conservation }\end{array}$ & $\begin{array}{c}00 \\
(0.00)\end{array}$ & $\begin{array}{c}23 \\
(16.20)\end{array}$ & $\begin{array}{c}55 \\
(38.73)\end{array}$ & $\begin{array}{c}42 \\
(29.58)\end{array}$ & $\begin{array}{c}22 \\
(15.49)\end{array}$ & $2.56^{\mathrm{b}}$ & 9 \\
\hline $\begin{array}{l}\text { Due to agroforestry, the human nutrition and health } \\
\text { is improved by increasing quality and diversity of } \\
\text { foods }\end{array}$ & $\begin{array}{c}03 \\
(2.11)\end{array}$ & $\begin{array}{c}36 \\
(25.35)\end{array}$ & $\begin{array}{c}40 \\
(28.17)\end{array}$ & $\begin{array}{c}44 \\
(30.99)\end{array}$ & $\begin{array}{c}19 \\
(13.38)\end{array}$ & $2.71^{\mathrm{b}}$ & 7 \\
\hline
\end{tabular}

$\mathrm{SA}=$ Strongly agree, $\mathrm{A}=\mathrm{Agree}, \mathrm{U}=$ Undecided, $\mathrm{D}=$ Disagree, $\mathrm{SDA}=$ Strongly disagree, WMS= Weighted mean score, Figures in the parentheses indicate percentages; Means followed by different superscript letters within the column are significantly different $(\mathrm{p}<0.05)$

Table 4. Forest resources preferences in agroforestry among rural societies of Kashmir (N=142).

\begin{tabular}{|c|c|c|c|c|c|}
\hline \multirow[t]{2}{*}{ Forest resource } & \multicolumn{3}{|c|}{ Preference } & \multirow[t]{2}{*}{ WMS } & \multirow{2}{*}{$\begin{array}{c}\text { Mean } \\
\text { rank }\end{array}$} \\
\hline & Highly preferred & Moderately preferred & $\begin{array}{c}\text { Least pre- } \\
\text { ferred }\end{array}$ & & \\
\hline Fuel wood & $142(100)$ & $00(0.00)$ & $00(0.00)$ & $3.00^{\mathrm{a}}$ & 1 \\
\hline Fodder & $140(98.59)$ & $00(0.00)$ & $02(1.41)$ & $2.97^{\mathrm{a}}$ & 2 \\
\hline Vegetable & $46(32.39)$ & $87(61.27)$ & $09(6.34)$ & $2.26^{\mathrm{b}}$ & 3 \\
\hline Timber & $04(2.82)$ & $67(47.18)$ & $71(50.00)$ & $1.53^{\mathrm{b}}$ & 5 \\
\hline Fruit & $05(3.52)$ & $105(73.94)$ & $32(22.54)$ & $1.81^{\mathrm{b}}$ & 4 \\
\hline Fibre/ floss & $00(0.00)$ & $37(26.06)$ & $105(73.94)$ & $1.26^{\mathrm{c}}$ & 8 \\
\hline Oilseeds & $00(0.00)$ & $28(19.72)$ & $114(80.28)$ & $1.20^{\mathrm{c}}$ & 9 \\
\hline Medicine & $04(2.82)$ & $44(30.99)$ & $94(66.19)$ & $1.37^{\mathrm{c}}$ & 6 \\
\hline Cottage industry/ handicrafts & $00(0.00)$ & $41(28.87)$ & $101(71.13)$ & $1.29^{\mathrm{c}}$ & 7 \\
\hline Animals/ birds/ insects etc. & $00(0.00)$ & $24(16.90)$ & $118(83.10)$ & $1.17^{\mathrm{c}}$ & 10 \\
\hline
\end{tabular}

WMS $=$ Weighted mean score, Figures in the parentheses indicate percentages; Means followed by different superscript letters within the column are significantly different $(\mathrm{p}<0.05)$

mir province located between geographical coordinates of $24.03^{\circ} 06^{\prime} \mathrm{N}$ Longitude and $74.26^{\circ} 45^{\prime} \mathrm{E}$ Latitude at an altitude of 1593 meter above mean sea level. The region is characterized by temperate monsoon type of climate. The mean minimum (January) and maximum (June) temperatures are $29.8^{\circ} \mathrm{C}$ and $1.92^{\circ} \mathrm{C}$, respectively, with average annual precipitation of $1163.2 \mathrm{~mm}$. Land use in the region is mostly dominated by cultivated land, permanent pastures, nonagricultural uses, barren and uncultivable land, other fallows, current fallows, forest land and tree cover and groves. The area studied in the districts was the stretch along Langate Forest Division of Jammu and Kashmir
(Anonymous, 2011).

Sampling: Multi-stage random sampling technique (Ray and Mondol, 2004) was used to select the villages and respondents. The first stage was the random selection of two blocks namely, Langate of Handwara tehsil in Kupwara district and Dangiwaha of Rohama tehsil in Baramulla district. The second stage involved simple random sampling of three villages viz., Yunsu, Chogal and Wahipora from Langate block and two villages viz., Ganipora and Behrampura from Dangiwacha block. A total of 142 households were selected from the sample villages having 10 percent sampling intensity by simple random sampling technique for the 
Table 5. Correlation between selected socioeconomic variables with perception, attitude and preference in agroforestry $(\mathrm{N}=142)$.

\begin{tabular}{lccc}
\hline Socioeconomic characteristic & Perception & $\begin{array}{c}\text { Co-efficient of correlation }(\mathbf{r}) \\
\text { Attitude }\end{array}$ & Preference \\
\hline Age & $-0.106 \mathrm{NS}$ & $-0.149 \mathrm{NS}$ & $-0.162 \mathrm{NS}$ \\
Education & $0.674^{*}$ & $0.653^{*}$ & $0.516^{*}$ \\
Social participation & $0.592^{*}$ & $0.534^{*}$ & $0.430^{*}$ \\
Family composition & $0.513^{*}$ & $0.502^{*}$ & $0.467^{*}$ \\
Size of land holding & $0.686^{*}$ & $0.692^{*}$ & $0.547^{*}$ \\
Main occupation & $0.550^{*}$ & $0.595^{*}$ & $0.449^{*}$ \\
Housing status & $0.402^{*}$ & $0.346^{*}$ & $0.353^{*}$ \\
Farm power & $0.422^{*}$ & $0.351^{*}$ & $0.344^{*}$ \\
Farm implements & $0.465^{*}$ & $0.448^{*}$ & $0.360^{*}$ \\
Livestock possession & $0.550^{*}$ & $0.479^{*}$ & $0.341^{*}$ \\
Wealth status & $0.386^{*}$ & $0.381^{*}$ & $0.324^{*}$ \\
Gross annual income & $0.536^{*}$ & $0.592^{*}$ & $0.329^{*}$ \\
\hline
\end{tabular}

*= Significant $(\mathrm{p}<0.05), \mathrm{NS}=$ Non-Significant

field study. The respondents interviewed were either household heads or eldest members.

Collection of data: Data were collected using a well structured pre-tested interview schedule and direct observation (Kumar, 2012). The interview schedule had four sections: (i) information on socio-economic profiles (ii) perceptions about agroforestry values (iii) attitudes toward the agroforestry benefits and (iv) forest resources preferences in agroforestry. The socioeconomic characteristics studied were age, education, social participation, family composition, size of land holding, main occupation, housing status, farm power, farm implements, livestock possession, wealth status and gross annual income (Venkataramaiah, 1990). To get the rural people's perception towards the agroforestry values in their daily life, ten broad classes of agroforestry values were incorporated in the schedule and their degree of importance were measured by a 3point continuum scale namely, very important, moderately important and least important with their respective scores 3, 2 and 1 as per Singha et al. (2006). The ranking of agroforestry values was done from 1 to 10 on the basis of the mean score to determine their relative importance. The attitude of rural people towards agroforestry benefits was measured using a scale developed by Sreenath and Veerabhadraiah (1993). The attitude scale was consisted of ten especially collected statements from agroforestry farmers, relevant professionals and available literatures related to the agroforestry benefits. The statements were scrutinized and edited as per criteria set up by Edwards (1969). The respondents were asked to respond to each statement in terms of their agreement or disagreement on five point continuum viz., strongly agree, agree, undecided, disagree and strongly disagree with their respective scores of 5, 4, 3, 2 and 1. Ranking technique based on mean cumulative scores was applied to find out the level of favouritism or un-favouritism towards agroforestry benefits. Forest resources preference was measured employing the scale of Nagesha and Gangadharappa (2006). A set of ten important categories of forests resources was listed in the schedule and the preference level of each resource was recorded as highly preferred, moderately preferred and least preferred assigning the scores 3,2 and 1, respectively. The relative preferences of various forest resources were worked out by ranking technique based on mean cumulative scores.

Data analysis: The observed data were analyzed on MS Excel and Statistical Package for Social Sciences (SPSS) software with the level of significance set at $p$ $<0.05$. The statistical tools viz., frequency (f), percentage $(\%)$, average (x), standard deviation, range, coefficient of correlation and $\mathrm{F}$ test were applied for analysis of the data as per Snedecor and Cochran (1967). The mean rank score for each item was obtained by multiplying the frequencies with their respective scores, adding them up and dividing by the total number of respondents as follows:

Weighted Mean Score (WMS) $=\frac{\sum \mathrm{s}_{\mathrm{i}} \mathrm{f}_{\mathrm{i}}}{\mathrm{n}}$

where, $f_{i}=$ frequency of the respondents for ith item

$\mathrm{Si}=$ score of the ith item

$\mathrm{I}=0,1,2,3,4$ or 5

$\mathrm{n}=$ total number of respondents

\section{RESULTS AND DISCUSSION}

Socioeconomic characteristics of rural people: The socioeconomic variables averaged for the rural households (Table 1) specified the predominance of middle aged people (41.75 years) having low literacy (2.89), membership of only one organization (1.14), nuclear and large sized families (2.90), marginal sized land holding (1.15), engaged mainly in agriculture (2.80), owning one mixed or pucca house (3.57), one pair of bullocks (1.04), low farm implements possession (9.64), 6 to 10 livestock (1.91), low wealth status (8.09) and earning average gross annual income of Rs. 50887.32 .

The middle aged people (31-50 years) are the actual earners who are generally economically active, enthusiastic, innovative and hard working in the rural societies (Sinha et al., 2010). The low literacy is due to un- 
satisfactory socioeconomic conditions, lack of educational facilities, higher involvement of youths in livelihood earnings and apathy towards higher education (Pal, 2011). The social participation shows the grousing magnitude of interest and willingness of the rural people towards involvement with various formal and informal organizations (Prakash and Sharma, 2008). The prevalence of nuclear and large sized families in the rural households is due to emergent individualism leading to independent life with personal assets and proper accommodation (Kumar et al., 2010). The nuclear and neo-local structure of families in the rural communities advocated early fragmentation of land from generation to generation and among married offsprings resulting in marginal size of land holding (Ajake and Enang, 2012). Agriculture being the prevailing main occupation and back bone of the economy in the area, most of the households either belong to farming families or dependent on farming for their livelihood (Gupta et al., 2009). The unsatisfactory housing status could be attributed to low socioeconomic condition, poverty, lack of infrastructure, rural environment etc. (Islam, 2008). To support farming and allied activities possession of at least one pair of bullocks became imperative for rural households (Singh et al., 2007). Similarly, farming and allied activities being major source of livelihood of the households, the possession of minimal farm implements is indispensable (Gupta et al., 2009). Holding good number of livestock could be attributed to the fact that livestock rearing was the most preferred secondary occupation (Pal, 2011). Although different and varied types of domestic materials were possessed by the households, the overall picture was not satisfactory, especially in the context of the improved, modern and prestigious material resources. Poverty, low literacy, lack of knowledge, lack of exposure, infrastructural insufficiency etc. is the main reason for such scenario (Islam, 2008). The probable reasons for preponderance of families having medium gross annual income (Rs. 30000 to $60000 /$ annum) might be that majority of people are either farmer having small sized land holding or petty traders (Bijalwan et al., 2011).

Perceptions about agroforestry values: The local people's perception of the agroforestry values (Table 2) indicated that the productive values (WMS, 2.85) were considered most important among majority $(84.51 \%)$ of the respondents and assigned $1^{\text {st }}$ rank. This is a fair reflection because the productive values of agroforestry make rural people self-reliant meeting their basic needs in terms of fuel wood, fodder, timber, fruits, fibre, food, vegetables etc. Likewise, a substantial majority $(83.10 \%)$ of the respondents contemplated the economic values (WMS, 2.83) as most important and was rated as $2^{\text {nd }}$. This is because the economic aids from agroforestry like increased family income, employment opportunities, improvement in livestock possession, supplementary income, decreased farm expenditure etc. ease off the livelihood stress in the rural communities. Regarding the human values (WMS, 2.74) of agroforestry, most of the respondents $(75.35 \%)$ rated them as most important and ranked $3^{\text {rd }}$. This could be attributed to the fact that the human values directly contribute to the improvement in education, occupational skill, occupational knowledge, information access, health and nutrition etc. in the rural societies. The social values (WMS, 2.44) of agroforestry were perceived as most important $(53.52 \%)$ and moderately important $(37.32 \%)$ by the respondents ranking them as $4^{\text {th }}$, which is consistent due to improvement in food habits, communication exposure, migration check, transformation in nature of occupation etc. The respondents rated the protective values (WMS, 2.42) of agroforestry as most important $(52.82 \%)$ and moderately important $(36.62 \%)$ giving them $5^{\text {th }}$ rank, which is existed because of its intangible benefits as soil and water conservation, erosion control, flood control, reduction in incidence of pests and diseases etc. The productive, economic, human, social and protective services of agroforestry were assigned higher values due to their socioeconomic and life supporting impact to the rural societies, which is in consistent with the previous workers (Kareemulla et al., 2009; Bijalwan et al., 2011).

With respect to the ecological values (carbon sequestration, pollution reduction, biodiversity conservation, protection of wildlife habitat, groundwater recharge, reduction in dependency on natural forest, climate changes etc.), recreational values (religious ceremonies, enhancement of landscape, creation of aesthetic venue, religious sacrifices, entertainment opportunities, propitiation of gods, sports, hunting etc.), cultural values (maintenance of local cultural heritage, promotion of habits, totems, festivals, taboos, folklore, traditional recipes etc.), organizational values (rights or claims, friends, kin, support from trade or professional associations, families, communities, committees, businesses, voluntary organizations, political claims etc.) and spiritual values (preservation of spirituals, values, beliefs, customary rituals) provided by the agroforestry to the rural societies, the perceptions expressed by majority of the respondents were moderate having WMS varying between 2.27 to 1.97 and thus, the ranks assigned were 6 to 10 respectively. An explanation for this could be that these agroforestry values are nonmaterial and non-instrumental in nature, the importance realization of which is incomprehensible in the rural societies. Secondly, considerable activities were women oriented, where men attributed a lower importance and assigned lower values as compared to women. The F statistics $(\mathrm{p}<0.05)$ showed that the material values of agroforestry (productive, economic and human) were significantly different to the nonmaterial values (protective, social, ecological, cultural, recreational, spiritual and organizational) because the contributions of material values are easily assessable while the non-material values are least observable in the rural societies. The material values of agroforestry 
were rated higher as compared to the non-material values, which is similar to the other studies (Nagesha and Gangadharappa, 2006; Banyal et al., 2011).

Attitudes towards agroforestry benefits: As Table 3 demonstrates, the majority of the respondents agreed with the attitude statements namely, agroforestry helps people to become self-reliant in terms of fuel wood, fodder, timber and other non-timber forest produces (WMS, 4.28), agroforestry operations gives employment and income opportunities to the people at their door steps (WMS, 4.23) and supply of raw materials for forest resources based cottage industries and handicrafts is sufficient in the area (WMS, 4.17) and ranked them 1, 2 and 3 respectively. This is because that these components were visual in nature which the respondents could directly observe and satisfied to a greater extent. The majority of the respondents expressed indifference towards the attitude statements related to agroforestry viz., people can improve their socioeconomic conditions by adopting the agroforestry enterprises (WMS, 3.47), the agroforestry is successful in meeting social, cultural, religious and recreational needs of the people (WMS, 3.32), agroforestry reduces exodus of rural people to urban areas for their livelihood (WMS, 2.98), due to agroforestry, the human nutrition and health is improved by increasing quality and diversity of foods (WMS, 2.71), agroforestry practices assures maintenance of ecological balance (WMS, 2.59), adoption of agroforestry helps in soil and water conservation (WMS, 2.56) and practice of agroforestry has helped in amelioration of the microclimate of the area (WMS, 2.48) and ranked them 4 to 10 respectively. This could be articulated to the facts that these items were intangible to the people and least observable in nature which makes them unable to assess and realize these benefits. The F statistics ( $p<$ 0.05 ) showed significant statistical differences between the tangible and intangible benefits of agroforestry which is strictly linked to magnitude of livelihood dependence on forest resources, protective and productive influences of agroforestry, contribution of agroforestry to social, economic, cultural, environmental and rural development, tree consciousness and love of tree among the people, agroforestry based traditional life, indigenous habitat etc. A number of studies confirm that people have highly supportive attitude towards tangible benefits of agroforestry, while they attribute a lower importance to intangible benefits (Sreenath and Veerabhadraiah, 1993; Durai et al., 2005; Islam et al., 2006).

Resources preferences in agroforestry: Significant majorities of respondents (100 and 98.59\%) expressed higher preference for fuel wood (WMS, 3.00) and fodder (WMS, 2.96) and assigned them the ranks 1 and 2 respectively (Table 4). Fuel wood is the principal traditional source of energy constituting maximum share in total bio-fuels consumption in the rural societies. The fuel wood is consumed mostly for cooking, heating, cottage industries (bakery, basketry and matting, bamboo works, hotels, brick manufacture, sericulture etc.), community functions (festivals, feasts etc.) and some other purposes such as marriage, child christening etc. Almost all the households depend on fuel wood as they have less access to other energy sources such as LPG, kerosene, coal etc. while there is a wide range of fuel wood species in the area. The major forms in which fuel wood is consumed in domestic households and rural industries are billets, twigs, wood shavings, saw dust and even leaves. Similarly, almost all the households procure a major portion of their fodder requirement from agroforests for by grazing livestock, lopping leaf fodder or collecting green herbage. The utilization of fuel wood and fodder is thus, very frequent on daily basis and at higher level. With regards to fuel wood and fodder, earlier studies (Singha et al., 2006; Islam et al., 2015) found that rural people value these resources more than other forest resources.

The preference of vegetable (WMS, 2.26), fruit (WMS, 1.81) and timber (WMS, 1.53) among majority (47.18 to $73.94 \%)$ of the respondents were moderate placing them at the ranks 3,4 and 5 respectively. Vegetables and fruits collected from agroforestry are the major food materials; essential means of nutrition and a source of family income for the rural people, the frequency and volume of utilization of these forest products is quite withstanding. These findings are in conformity with the work of Pandey (2009), who found that vegetable and fruit are the moderately preferred forest resources in agroforestry because these resources were procured from other sources.

Timber is extensively used for various purposes like furniture and fixtures, agricultural implements, fencing, hutments, housing, furniture, mine props, packaging, match wood, sports goods, scaffolding, poles etc. Primarily in the rural societies, most of the population depends on agroforestry directly to meet the bulk of timber requirement. In contrast to people living proximate to forests, those living distant to forests assigned a higher preference to timber than other productss in agroforestry (Rout and Panda, 2011).

With respect to the medicine (WMS, 1.37), cottage industry/ handicrafts (WMS, 1.29), fiber/ floss (WMS, 1.26), oilseeds (WMS, 1.20) and animals/ birds/ insects etc. (WMS, 1.17), most of the respondents (66.19 to $83.10 \%$ ) have expressed low preference and rated these resources from 6 to 10 ranks because the household consumption or sale of these forest resources is occasional in times of needs. The F statistics ( $p<0.05)$ confirmed significant statistical differences among the forest resources groups, which is strictly linked to the diversity and quantity of use of the forest resources accruing the benefits in terms of supply of basic needs, saving of cash resources, safety-net during times of misfortune, habitat and shelter, employment and income generation in agroforestry enterprises, cultural and spiritual benefits and environmental services to the 
rural societies. These findings are in line with other studies on resources preferences in agroforestry that focus on people living in rural areas (Singh and Quli, 2011; Sati and Song, 2012).

Correlation analysis: The socio-economic characteristics such as education, social participation, family composition, size of land holding, main occupation, housing status, farm power, farm implements, livestock possession, wealth status and gross annual income had exhibited positive and significant correlation with the perceptions, attitudes and preferences in agroforestry, whereas, the age had shown a non-significant correlation (Table 5). The results signified that the socio-economic variables included in the study are crucial determinants for the perceptions, attitudes and preferences in agroforestry among the rural societies. The magnitude of perceptions, attitudes and preferences in agroforestry varied greatly between low educated and high educated people, marginal farmers and large farmers, bigger families and smaller families, poorer households and wealthier households and low income group and high income group. The extents of perceptions, attitudes and preferences in agroforestry were higher for the households having higher social participation, occupational status, housing status, farm power, farm implements and livestock possession. Contrary to this the families with lower social participation, occupational status, housing status, farm power, farm implements and livestock possession have shown reverse trend.

The heterogeneity in households with respect to economic and social status, perspectives, knowledge systems, values, understanding and objectives are fundamental dimensions of the rural societies. Therefore, policies based up on the assumptions of rural cohesiveness and homogeneity cannot assure the symmetric pattern of perceptions, attitudes and preferences in agroforestry in the rural societies In this light, it can be inferred that the priorities to increase the levels of perceptions, attitudes and preferences in agroforestry will differ due to different socio-economic capacity of the households in the rural societies. This study confirmed the importance of socio-economic characteristics in people's perceptions, attitudes and preferences in agroforestry, which has been underlined by other studies (Adhikari, 2005; Nagesha and Gangadharappa, 2006; Kareemulla et al., 2009; Bijalwan et al., 2011).

\section{Conclusion}

The perceptions of the material values of agroforestry (productive, economic and human) were most important while the non-material values of agroforestry (protective, social, ecological, cultural, recreational, spiritual and organizational) were perceived as the moderately important. People's attitudes towards the tangible benefits of agroforestry were highly favourable whereas attitudes as regards intangible benefits were indifferent. The rural people expressed higher preference for fuel wood, fodder, vegetable, fruit, and timber while moderate or low preferences were observed for medicine, cottage industry/ handicrafts, fiber/ floss, oilseeds and animals/ birds/ insects etc. A robust relationship was exhibited between socioeconomic attributes and people's perceptions, attitudes and preferences in agroforestry. As the rural societies are not homogeneous entities that can be isolated and identified by single objective and common interests, prior to devolution programme, policy makers should first acknowledge heterogeneity nature of rural societies rather than starting from a general assumption of cohesiveness and homogeneity. The need to include the human behaviours and socioeconomic background is recommended for designing, constructing and implementing policies in agroforestry develoment and the policies should consider the differentials in perceptions, attitudes, and preferences in agroforestry according to inequality and heterogeneity of the societies. This study offered useful insights for reinforcing the linkage between human welfare, livelihoods and agroforestry.

\section{ACKNOWLEDGEMENTS}

Our deep thanks to everyone who brought their contributions to this paper, and for kindly sharing ideas, comments, and suggestions. Special thanks to Forestry scholars of the Faculty of Forestry, SKUAST-K, Wadura, Sopore, Kashmir for providing support during our field-work.

\section{REFERENCES}

Adhikari, B. (2005). Poverty, Property Rights and Collective Action: Understanding the Distributive Aspects of Common Property Resource Management. Environ Dev Econ., 10: 7-31.

Ajake, A.O. and Enang, E.E. (2012). Demographic and socioeconomic attributes affecting forest ecosystem exploitation and management in the rural communities of cross river state, Nigeria. Ame. Inter. J. Contem. Res., 2(1): 174-184.

Anonymous (2011). Directorate of Economics and Statistics, District Statistics and Evaluation Office, Baramulla, Jammu and Kashmir.

Banyal, R., Masoodi, N.A., Masoodi, T.H., Sharma, L.K. and Gangoo, S.A. (2011). Knowledge and attitude of farmers towards agroforestry practices in north Kashmir- a case study. The Indian For., 137(12): 1377-1381.

Bijalwan, A., Sharma, C.M. and Kediyal, V.K. (2011). Socioeconomic status and livelihood support through traditional agroforestry systems in hill and mountain agroecosystem of Garhwal Himalaya, India. The Indian For., 138(12): 1423-1430.

Dagar, J.C. (2012). Utilization of degraded lands/ habitats and poor quality water for livelihood security and mitigating climate change. Indian J. of Agroforestry, 14(1): 1-16.

Durai, V., Sankar, S. and Chandrashekhara, U.M. (2005). Attitude of the farmers on tree species cultivation in homestead farming. Journal of Non-Timber Forest Products, 12(3): 151-156.

Edwards, A.L. (1969). Techniques of attitude scale construction. 
Vakils, Feffer and Simons Private Ltd., Mumbai.

Edwards, D.M., Jay, M., Jensen, F.S., Lucas, B., Marzano, M., Montagné, C., Peace, A. and Weiss, G. (2012). Public preferences across Europe for different forest stand types as sites for recreation. Ecology and Society, 17(1): 27-36.

Gupta, T., Gupta, R.K. and Raina, K.K. (2009). Socioeconomic factors associated with fuel consumption pattern in rural habitation of Jammu region, Jammu \& Kashmir. Indian J. For., 32(3): 387-390.

Islam, M.A. (2008). Availability and consumption pattern of fuel wood, fodder and small timber in rural Kashmir. Environment and Ecology, 26(4A): 1835-1840.

Islam, M.A., Banyal, R., Rai, R. and Singh, P.K. (2012). Determinant factors of agroforestry adoption in North Kashmir. Indian j Soc Res., 53(2): 123-129.

Islam, M.A., Masoodi, N.A. and Gangoo, S.A. (2005). Knowledge and adoption of agroforestry practices among farmers in North Kashmir. Journal of Extension Education, 9/10 (1\&2): 12-18.

Islam, M.A., Masoodi, N.A., Masoodi, T.H. and Gangoo, S.A. (2006). Attitude of farmers towards agroforestry plantation in North Kashmir. Journal of Research (BAU), 18(1): 199-204.

Islam, M.A., Quli, S.M.S., Rai, R., Ali, Angrej and Gangoo, S.A. (2015). Forest biomass flow for fuel wood, fodder and timber security among tribal communities of Jharkhand. Journal of Environmental Biology, 36(1): 221-228.

Kareemulla, K., Rizvi, R.H., Yadav, R.S., Munnaram and Dhyani, S.K. (2009). Agroforestry for rural development - cooperatives as viable institutions. Agricult. Situ. India., May, 2009, pp. 61-67.

Khandagale, A.S., Taide, Y.B., Deshmukh, H.K. and Thigale, M.B. (2012). Constraints faced by growers in adoption of recommended practices of teak. Indian J. of Agroforestry, 14(1): 45-48.

Kumar, P, Rawat, L. and Basera, H. (2010). Socioeconomic studies of Henwal Watershed, Tehri Garhwal, Uttarakhand. Indian J. For., 33(2): 149-154.

Kumar, R. (2012). Research Methodology - A step by step guide for beginners. Dorling Kindersley (India) Pvt. Ltd., New Delhi, india.

Macura, B., Zorondo-Rodríguez, F., Grau-Satorras, M., Demps, K., Laval, M., Garcia, C.A. and Reyes-García, V. (2011). Local community attitudes toward forests outside protected areas in India- Impact of legal awareness, trust, and participation. Ecology and Society, 16(3): 10-20.

Mukherjee, D. (2013). Studies on Resource Management for Sustainable Ecosystem of Eastern Himalaya. Asian Journal of Agriculture and Food Science, 1(5): 222-235.

Mushtaq, T., Sood, K.K. and Raina, N.S. (2012). Species preferences for fuel wood in Shiwalik Himalayas- Implications for agroforestry plantations. Indian J Hill Fmg., 25(2): 18-21.

Nagesha, G. and Gangadharappa, N.B. (2006). Adoption of agroforestry systems in north eastern districts of Karnataka. My Forest, 42(4): 337-347.

Pal, G. (2011). Socio-economic characteristics of lac growers in Kanker district of Chhattisgarh. The Indian For., 137(11): 1294-1297.

Palett, A., Isabella, D.M., Cantiani, M.G. and Maino, F. (2013). Social perceptions and forest management strategies in an Italian Alpine community. Mountain Research and Development, 33(2):152-160.

Pandey, R. (2009). Forest resource utilization by tribal commu- nity of Jaunsar, Uttarakhand. The Indian For., 135(5): 655662.

Pant, N. (2011). Motivational factors in activities of agroforestry - a case study. The Indian For., 137(3): 363-569.

Prakash, O. and Sharma, R. (2008) Determining people's participation in forest fire control: A study of Himachal Pradesh. Indian J. For., 31(1): 1-6.

Quli, S.M.S. and Singh, P.K. (2010). Choice of species for traditional agroforestry by tribes in Jharkhand. Jharkhand $J$. Develop. Manag. Stud., 8(1): 3727-3735.

Ratsimbazafy, C.L., Harada, K. and Yamamura, M. (2012). Forest resources use, attitude and perception of local residents towards community based forest management: Case of the Makira Reducing Emissions from Deforestation and Forest Degradation (REDD) Project, Madagascar. J. Ecol. Nat. Environ., 4(13): 321-332.

Rawat, Y.S. and Vishvakarma, S.C.R. (2011). Pattern of fodder utilization in relation to sustainability under indigenous agroforestry systems, North-Western Himalaya, India. Environ. We Int. J. Sci. Tech., (6): 1-13.

Ray, G.L. and Mondol, S. (2004). Research Methods in Social Sciences and Extension Education, Kalyani Publishers, New Delhi, 66-76.

Reddy, E.V. (2011). Constraints in marketing of agroforestry produce in India. The Indian For., 137(6): 669-677.

Rout, S.D. and Panda, S.K. (2011). Seasonal availability of nontimber forest products collected by the tribals in Gandigadha Reserve Forests of district Mayurbhanj, Orissa. The Indian For., 137(11): 1289-1293.

Roy, M.M. and Tiwari, J.C. (2012). Agroforestry for climate resilient agriculture and livelihood in arid region of India. Indian J. of Agroforestry, 14(1): 49-59.

Sati, V.P. and Song, C. (2012). Estimation of forest biomass flow in the montane mainland of the Uttarakhand Himalaya. Inter. J. For. Soil Erosion., 2(1): 1-7.

Singh, P., Tewari, P. and Rani, S. (2007). Socio-economic status of rural households in Kumaon region of Uttarakhand. Pantnagar Journal of Research, 5(1): 146-150.

Singh, P.K. and Quli, S.M.S. (2011). Economic valuation of non -timber forest product's contribution in tribal livelihood in West Singhbhum district of Jharkhand. The Indian For., 137(11): 1258-1264.

Singha, A.K., Talukdar, R.K. and Singha, J.K. (2006). Maintenance behaviour of forest resources by the people of forest villagers in Assam. Indian J. For., 29 (1): 47-54.

Sinha, B., Kala, C.P. and Katiyar, A.S. (2010) Enhancing livelihoods of forest dependent communities through synergizing FDA activities with other development programs. RCNAEB sponsored project, Indian Institute of Forest Management (IIFM), Bhopal.

Snedecor, G.W. and Cochran, W.G. (1967). Statistical Methods. Iowa State University Press, Ames, Iowa-50010.

Sood, K.K., Najiar, C., Singh, K.A., Handique, P., Singh, B. and Rethy, P. (2008). Association between socio-economic parameters and agroforestry uptake: evidences from eastern Himalaya, Indian J. For., 31(4): 559-564.

Sreenath, D. and Veerabhadraiah, V. (1993). A study on the attitude of farmers towards social forestry programme. $M y$ Forest, 29(2): 117-120.

Venkataramaiah, P. (1990). Development of socio-economic status scale, Ph.D. Thesis, Department of Agricultural Extension, UAS, Bangalore. 